\title{
The Study on Effects of Foreign Ownership on Innovation
}

\author{
June Y. Lee ${ }^{1} \&$ Dongwoo Yang ${ }^{2}$ \\ ${ }^{1}$ Department of Management Science \& Engineering, School of Engineering, Stanford University, Stanford, CA, \\ USA \\ ${ }^{2}$ Graduate School of Venture, Hoseo University, Seoul, South Korea \\ Correspondence: June Y. Lee, Department of Management Science \& Engineering, School of Engineering, \\ Stanford University, Stanford, CA 94305, USA. E-mail: juneylee@stanford.edu
}

Received: September 29, 2016

Accepted: October 17, 2016

Online Published: October 28, 2016

doi:10.20849/abr.v1i2.78

URL: http://dx.doi.org/10.20849/abr.v1i2.78

\begin{abstract}
In developing countries, government actively promotes foreign investment in order to adapt the new and latest technology. This leads to greater R\&D activities, thus this creates knowledge and technology spillover. In this paper, we look at Korea where the R\&D has been the main factor of rapid growth. We study the effects of foreign ownership on technological performance by looking at $756 \mathrm{R} \& \mathrm{D}$ intensive Korean firms from 1999 to 2009. We look the number of applied and registered patents are dependent variables (as a technological performance) and observe statistically significant and positive correlation with foreign ownership due to three main reasons: (a) knowledge and technology spillover, (b) relatively more risk-taking investment behavior of institutional investors, and (c) cherry-picking strategy of investing in firms that perform well. Furthermore, we also observe the R\&D expenditure has a strong and positive correlation with the number of applied and registered patents, and R\&D expenditure could serve as a proxy variable for technologically advanced industries. Lastly, we observe that the coefficients increase for applied and registered patents for different technology index sub-groups.
\end{abstract}

Keywords: foreign ownership, innovation, patents, technology spillover, knowledge spillover

\section{Introduction}

Innovation is necessary for latecomer countries to generate sustainable growth, and many previous studies tried to understand the key drivers of innovation. One way of addressing this question is by looking at the decision making process of innovation generating activities such as research and development $(R \& D)$. While there have been several studies of the effects of foreign ownership (or foreign direct investment, FDI) on economic performance, there has been only a few studies understanding foreign ownership impacting technological performance. Economic performance uses proxies such as return on asset (ROA), sales, annual growth rate, value added, and profits, but technological performance is much more challenging to measure because technological efforts are the most commonly measured through $R \& D$ expenditure or R\&D intensity. There are three major reasons of explaining the positive correlation between foreign ownership and economic or technological performance: (a) knowledge, technology, or resources transfer (b) operational, human, and financial resources, and (c) cherry-picking strategies (Blomstrom \& Sjoholm, 1999; Boardman, Shapiro \& Vining, 1997; Chhibber \& Majumdar, 1999; Chuang \& Lin, 2007; Cyert \& March, 1963; Falk, 2008; Griffith, Redding, \& Simpson, 2004; Grinblatt \& Keloharju; 2000; Huang \& Shiu, 2009; Kinoshita, 2000; Liu,2002; Love, Ashcroft, \& Dunlop, 1996; Sasidharan \& Kathuria, 2011; Vishwasrao \& Bosshardt, 2001; Yudaeva, Kozlov, Melentieva, \& Ponomareva, 2003). On the other hand, some scholars explained the negative correlation for the following reasons: (a) misalignment of interests between domestic and foreign shareholders (i.e. agency costs) (b) tendency to license or purchase new technology, and (c) inability to understand the local culture (Bishop \& Wiseman, 1999; Choe, Kho \& Stulz, 2005; Dvorak, 2005; Kang \& Stulz, 1997; Knell \& Srholec, 2005; Kochhar \& David, 1996; Vishwasrao \& Bosshardt, 2001).

In this paper, we looked at $756 \mathrm{R} \& D$ intensive Korean firms based on their R\&D expenditure size as of 2009 and pulled firm and industry characteristics during the 1999-2009 period. As R\&D is considered as the main driver for innovation, so we analyze how technological performance is altered based on foreign ownership percentage. Korea is an interesting country to study for three reasons: First, Korea, along with other Asian countries, experienced major Asian financial crisis in 1997 and 1998 but recovered fairly quickly. The Asian financial crisis 
served as a turning point for Korea in changing its foreign investment policy, which will be discussed in the next section. Therefore, it is essential to understand to the implications and consequences of open foreign investment policy. Secondly, Korea is an example of successfully shifting from manufacturing and export-based economy in 1970s and 1980s to knowledge and technology-based economy in 2000s and 2010s. It now stands as one of the most technologically advanced countries, especially in the field of semiconductors, electronic, and automobiles. By studying the innovation path of Korea, we believe the lessons will be applicable to other developing countries such as India and China for effective technology adoption and execution of innovation. Lastly, Korea spends approximately $3.4 \%$ of its GDP on R\&D investments including both government and corporation funding, and this percentage is the second highest amongst the OECD countries. By observing the trends of foreign ownership, we can see how that influenced the R\&D spending over time, thus impacting the technological performance.

We chose to start from year 1999 because as Korea received financial assistance from the International Monetary Funds (IMF) of $\$ 57$ billion and completely removed the restriction in how much foreign investors can invest in Korean firms. We investigate this change in the next section as well. This will help policymakers of the developing countries in their open innovation landscape.

This study is different from the previous studies mentioned above in two aspects. First, we use the percentage of foreign ownership instead of FDI. Foreign ownership percentage gives more accurate perspective of how much of the control is foreign investors. Secondly, rather than using R\&D intensity as a measurement of innovation, we used two proxy variables: the number of applied and registered patents. Technological performance is measured by $R \& D$ intensity and $R \& D$ expenditure because it is assumed that technological efforts would lead to performance in R\&D intensive industries. However, there are both internal and external incentives for firms to engage in R\&D (e.g. tax credits or freeriding of research grants received from the government or partnering corporations) that we should not assume R\&D efforts always lead to performance. We argue that applying patents is the first indicator of technological performance, which on average takes two years in successfully registering. Registered patents, then, generate economic performance on average five to six years.

This paper is presented in the following format. Section 2 discusses the policy change of foreign investment, investment trends of foreign investors, and previous literature on the effects of foreign ownership on economic and technological performance. Section 3 introduces our empirical model including the sample data and variable sets, descriptive statistics, regression analysis, and the findings. Finally, Section 4 addresses the implications, contributions, limitation, and improvement areas of our study.

\section{Literature Review}

\subsection{Korea's Foreign Investment Policy}

In the case of Korea, foreign capital has been tightly monitored and governed by the government in two main ways: share ownership by foreign investors and market entry by Korean firms. As outlined in Table 1, Korea Exchange (KRX) was first opened in 1992 to foreign investors allowing investing in 10 firms with 3\% maximum ownership level per firm. After 6 years later, this was completely removed where a foreign investor can invest $100 \%$ in Korean companies up to 100 firms. By May of 1998, there was a drastic change from $50 \%$ in 1997 to $100 \%$ in 1998 in the percentage ownership per firm because Korea received financial assistance from IMF in order to recover from the Asian Financial Crisis. According to the Article 168 of the Financial Investment Services and Capital Markets Act, a foreign investor cannot own more than $40 \%$ of the total market value of the outstanding issues of shares of government-owned entities such as Korea Energy Power Corporation (KEPCO) or Korea Telecom (KT). This was to make sure that control was remained by the government.

Table 1. Change of foreign investor restrictions in Korea

(Unit: number, \%)

\begin{tabular}{cccccccccc}
\hline $\begin{array}{c}\text { Date } \\
(\mathrm{MM} / \mathrm{YYYY})\end{array}$ & $01 / 1992$ & $12 / 1994$ & $07 / 1995$ & $04 / 1996$ & $10 / 1996$ & $05 / 1997$ & $11 / 1997$ & $12 / 1997$ & $05 / 1998$ \\
\hline $\begin{array}{c}\text { Number of firm } \\
\text { restrictions }\end{array}$ & 10 & 12 & 15 & 18 & 20 & 23 & 26 & 50 & 100 \\
\hline $\begin{array}{c}\text { Maximum } \\
\text { ownership } \\
\text { percentage/firm }\end{array}$ & 3 & 3 & 3 & 4 & 5 & 6 & 7 & 50 & 100 \\
\hline
\end{tabular}

*Source: Korea Exchange, 2012 
Table 2 shows the actual investment trends of foreign investors investing in KRX between 2001 and 2011 . Comparing 2001 and 2011, there has not been much change - only $0.1 \%$ increase in 10 years. During the span of 10 years, foreign investors owned about $33.06 \%$ of KRX on average. However, foreign investors owned up to $40.1 \%$ of KRX due to appreciation devalued securities during the Asian Financial Crisis since 1998. In the case of Mexico, foreign investors own, on average, $50 \%$ of Brazil domestic market, and $60 \%$ for Brazil, respectively. Korea's policy pattern on foreign investment prior to 1998 was often referred as "anti-foreign." This monitor process was similar to other developing Asian countries such as China, Taiwan, and India as their markets are highly monitored and intervened by the government in order to reach for the national economic growth (EPB, 1981).

Table 2. Trends of foreign investor ownership in Korea Exchange (KRX)

(Unit: \%)

\begin{tabular}{cccccccccccc}
\hline Year & 2001 & 2002 & 2003 & 2004 & 2005 & 2006 & 2007 & 2008 & 2009 & 2010 & 2011 \\
\hline $\begin{array}{c}\text { Foreign investor } \\
\text { ownership percentage }\end{array}$ & 30.5 & 32.8 & 37.6 & 40.1 & 37.1 & 35.1 & 31.0 & 27.2 & 30.5 & 31.2 & 30.6 \\
\hline
\end{tabular}

*Source: Korea Exchange, 2012, http://www.krx.co.kr/m8/m8_1/m8_1_1/BHPKOR08001_01.jsp

Note: Foreign investor ownership percentage is defined as (Market value of total stocks owned by foreign investors) / (total market value of KOSPI and KOSDAQ market)

\subsection{Positive Effects of Foreign Ownership on Performance}

We look at both positive and negative effects of foreign ownership on both economic and technological performance, especially in developing countries. As many developing countries wish to obtain the growth in the most effective, and the unanswered questions is to what degree the market should be open to foreign investors without losing complete control. Many studies have used different proxy measurements to capture economic performance such as sales, value add, or profits. For example, Kinoshita (2000) examines effects of foreign ownership variables on the log of value added to the firm from Czech manufacturing sector. Foreign ownership was captured in two variables: a foreign joint venture dummy indicator and foreign employee presence ratio of foreign firms to all firms in the industry. The latter variable reflects competition effects for recruiting foreign talents in comparison to other firms. Interestingly, both of these variables turn out to be statistically insignificant. Only when foreign employee presence is combined with $R \& D$ intensity, this variable becomes statistically significant and positive. Furthermore, this result was significant for oligopolistic sectors including electrical, machinery, and radio \& TV as there was a significant rate of spillover from having foreign presence.

Moreover, Liu (2002) investigates empirically whether FDI generates externalities in the form of technology transfer using data on 29 manufacturing industries over the period from 1993 to 1998 in the Shenzhen Special Economic Zone of China. Liu finds that FDI has large and significant spillover effects in that it raises both the level and growth rate of productivity of manufacturing industries, and domestic sectors are the main recipients of the spillovers and benefit more than other external effects of FDI. Similarly, Blomstrom \& Sjoholm (1999) present an empirical analysis based on data by the Indonesian Central Bureau of Statistics in 1991, which suggests foreign ownership is an important determinant of productivity and value added, but the degree of foreign ownership in an establishment seems to have no effect on productivity. This implies that multinationals have information advantage and a wide range of technologies and to choose from when they invest abroad, adapt technology transfer, and to technology is further developed (Huang \& Shiu, 2009). Related supporting evidence has been proven by Grinblatt \& Keloharju (2000) as foreign investors are able to select the winners.

As another way of measuring performance, some literatures assess foreign ownership and R\&D expenditures or R\&D intensity because different shareholders are investing with their own agenda in the firm. For example, family owned firms might encounter conflict of interest when a significant portion of the firm is owned by outside investors. In the case of Scotland, Love, Ashcroft \& Dunlop (1996) looked at 4,000 establishments of manufacturing industry and measured the likelihood of innovating. The innovation variable, I, is a function of expected profit from innovation, market power, industry structures, corporate structure, and ownership. As part of the ownership variable, foreign-owned indicator is used; this has a statistically significant and positive correlation with innovation. This implies that foreign-owned subsidiaries are more likely to innovation compared to other domestic firms. Love, Ashcroft \& Dunlop (1996) explained foreign-owned firms have more internal 
support and financial and operational resources to innovate as opposed to domestic Scottish firms that are monitored and overseen more tightly by government and other agencies for receiving loans and grants. This suggests that innovation is likely to take place at large, external, resource-abundant, and multinational firms.

Looking at the same notion of innovation generated R\&D activities, Sasidharan \& Kathuria (2011) studies the entry of foreign investments in India and how this reform change in 1991 forces domestic firms to undertake R\&D activities or import technology so as to compete with them. Looking at a sample size of 1,843 Indian manufacturing firms operating during the period 1994-2005, there is a statistically significant positive correlation between foreign ownership and R\&D activities for sub-sample groups. FDI inflow induces foreign-owned firms in high tech industries and firms in minority ownership to invest in R\&D and that FDI and $\mathrm{R} \& \mathrm{D}$ are found to be complements when sample is divided on the bases of equity ownership.

In European Union countries, Falk (2008) also supports that foreign-owned firms are more innovative than domestic firms. With sample data of 11,4000 firms in Western and Eastern European firms, he identifies five different types of innovation: (1) introduction of new products (2) introduction of new products developed in-house (3) introduction of new market products that are new to the firm (4) introduction of new production processes, and (5) introduction of new production processes developed in-house. Similar to previous literature, Falk's study finds firm's characteristics variables such as firm size, new firm indicator, and exporting indicator to be more significant rather than foreign-owned variable itself. More specifically, if foreign owned firms share the same characteristics as domestic firms, innovation rate would be reduced significantly. Falk believes foreign ownership often leads to direct technology transfer and knowledge spillover.

Chuang \& Lin (2007) confirm that R\&D spillover effects occur during the process of FDI. Similar to other previous literature, labor quality, firm size, market structure, and export orientation all affect firm's R\&D activities. Completely foreign-owned firms have larger production scale, higher export orientation, and less capital and R\&D intensity. Their work, from looking at Taiwan's manufacturing firms, shows that partially foreign-owned firms have twice higher R\&D intensity than completely owned. R\&D intensity is defined as R\&D expenditure divided total sales. They also address the relationship between FDI and R\&D and conclude that they are complements rather than substitutes. A foreign presence fosters knowledge spillover, labor turnover, and technology transfer, which reduces local firms' incentives to strengthen their technical capability by independent investing in R\&D. Based on random sample of 8,846 firms, higher ratio of the FDI in the industry shows higher tendency of the firm to do R\&D. Additionally, foreign-owned firms have a greater trend to do R\&D than domestically owned firms.

Moreover, Yudaeva, Kozlov, Melentie \& Ponomarva (2003) compare Russian firms with FDI with domestically owned. It turns out that an increase in foreign shares suggests a greater value added to the firms. During the knowledge and technology spillover process, several factors are introduced: introduction of sophisticated technology, available pool of information and resources, increase in competition for innovation, and transfer of technology. These foreign-owned firms were further analyzed by size. Unlike other previous literature, they find that smaller firms tend to be easier for a foreign owner to manage because small firms are often more flexible. Griffith, Redding \& Simpson (2004) assess foreign ownership and R\&D activities performed by multinationals of both British-owned and foreign-owned by different sectors. The most R\&D intensive sectors are pharmaceuticals and chemicals sector. In three sectors (pharmaceuticals/chemicals, transport equipment/aerospace, and services), British-owned multinationals perform more R\&D compared to foreign-owned multinationals. In the remaining two spaces (mechanical engineering/electrical machinery and manufacturing), all multinationals perform similar level of R\&D. This can be explained by "cherry picking" strategy where foreign investors have already selected firms that are high performers, so as a result, there is bias embedded into the positive correlation.

Vishwasrao \& Bosshardt (2001) look at 1,400 medium to large firms from 1989 to 1993 and show that ownership issues are important indicators of number of collaborations. Foreign-owned firms are more likely to enter into collaboration agreements, and this change was more observant after 1991. In retrospect, government-owned firms are less likely to be open to new technology adoption.

Boardman, Shapiro \& Vining (1997) imply foreign firms tend to have superior performance, but this difference can be valued more than it actually is due to foreign and domestic agency costs. This is also related to more risk taking investment behavior of foreign investors (Cyert \& March, 1963). Likewise, it was shown that foreign firms are significantly more profitable and productive then domestic firms with comparable levels of ownership concentration. Chhibber \& Majumdar (1999) show a positive correlation between foreign ownership (low, medium, and high) impacts firm's performances in 1,000 Indian companies listed on Mumbai Stock Exchange, 
which is measured as return on sales and return on assets. They argue that it is not the ownership per se but the factors underlying ownership that matter. In other words, owning a greater share of a firm means more effective control, which translates to a higher level of profitability. This attracts more foreign investors to invest in superior firms.

\subsection{Negative Effects of Foreign Ownership on Performance}

Some studies prove the exact opposite showing the negative correlation between foreign ownership and economic or technological performance. For example, Kochhar \& David (1996) believe that different types of shareholders may have different interests in R\&D investments, and foreign owners have different interests than domestic owners, thus creates conflict of interest (Douma, George \& Kabir, 2006). Though FDI plays a significant role in international technology transfer, Knell \& Srholec (2005) conclude that foreign-owned firms are less likely to invest in their own R\&D activity compared to the local owned firms by analyzing 729 manufacturing companies in Czech. This implies that innovation cooperation with foreign partners may by a much more effective way to encourage international technological transfer than FDI if given time constraints and opportunity cost and high risk of having R\&D activity within. Furthermore, there is negative effect of foreign ownership through its impact on the likelihood of having an internal R\&D activity. Firms that engage in internal R\&D activity are proven to be more likely to have global partner for innovation cooperation. As foreign-owned firms are less likely to engage in internal R\&D activity, it creates the other indirect effect on probability of innovation cooperation. In short, foreign-owned firms when compared to domestic owned firms are less likely to transfer technology through the innovation cooperation.

Bishop \& Wiseman (1999) examine the impact of ownership and a variety of other variables on the likelihood of innovation and the presence of an R\&D function within a national sample of UK defense related firms. It is shown that foreign ownership has a negative indirect impact upon innovation for similar reasons - increase in international cooperation $R \& D$ opportunities leading to purchase of new technology rather than creating in-house. Vishwasrao \& Bosshardt (2001) find two interesting observations around policy change in 1991 in India. First, technological international collaborations are no longer associated with higher R\&D expenditure after liberalization in 1991. Domestic Indian firms would rather purchase foreign technology rather than establish internal R\&D division. Additionally, the foreign investment liberalization of 1991 has had a positive impact on technology adoption, and the majority of this change has been captured by foreign-owned firms. This raises a question around the effectiveness and advancement of domestic Indian firms from liberalization policy. Choe, Kho \& Stulz (2005) and Dvorak (2005) argue that domestic investors have information advantage in domestic markets in the case of Korea and Indonesia. This is certainly convincing as many of these studies have been conducted in developing countries where information is not as transparent or clearly translated for foreign investors. Kang \& Stulz (1997) also find that foreign investors do not outperform domestic investors using annual Japanese data.

\section{Empirical Analysis}

\subsection{Preliminary Analysis}

\subsubsection{Data Description}

Our sample data started with the list of top 1,000 Korean companies based on their R\&D expenditure as of 2009 . We then pulled data from two sources: National Information \& Credit Evaluation, Inc. (NICE) and Korea Intellectual Property Rights Information Service (KIPRIS). Founded in 1986, NICE is a credit rating agency similar to S\&P, Moody's, and Fitch Rating in the U.S. - for firms listed in Korean Stock Exchange. The database contains firm and industry based variables such as the number of employee, technology index, industry classification code, and R\&D expenditure. KIPRIS is an internet-based patent document search service that covers publications of Korean IPR applications, legal status information, and trial information. Korea Institute of Patent Information has been providing KIPRIS since 1996 on behalf of Korean Intellectual Property Office. KIPRIS is designed to promote the use of patent information for R\&D activities, patent disputes, and corporate mergers \& acquisitions. The database contains patent related data such as the number of applied and registered patents in Korea, Japan, U.S., and Europe of Korean companies.

\subsubsection{Variable Description}

Table 3 outlines six variables that we will in our empirical model. The OECD Science, Technology, and Industry Scoreboard in 2005 first introduced a new indicator categorize into low, medium, and high in terms of technological advancement. In order to control different levels of firm's technology levels, we are using technology index as a control variable. Furthermore, we are using Korean Standard Industrial Classification 
(KSIC), which was modeled after International Standard Industrial Classification (ISIC) of the United Nations. KSIC is determined based on the four principals: the characteristics of inputs of goods, service, and factors of production, the process and technology of production, the characteristics of the goods and services produced, and the use to which outputs are applied. Finally, we have pulled the number of applied and registered patents in Korea from KIPRIS. Table 4 outlines different industries that belong under 4 technology indexes defined by the OECD.

Table 3. Variables summary

\begin{tabular}{|c|c|}
\hline Variable Name & Description \\
\hline \multirow{2}{*}{ TECHNOLOGY_INDEX } & Technological advancement level by OECD standards \\
\hline & 0: Others 1: Low, 2: Medium-Low, 3: Medium-High, 4: High \\
\hline IND2 & $\begin{array}{l}\text { Korean Standard Industrial Classification (KSIC) code assigned by the Korean } \\
\text { Standard Statistical Classification (KSTC) }\end{array}$ \\
\hline EMPL_NUM & The number of employees \\
\hline LN(EMPL_NUM) & Natural log form of the number of employees \\
\hline RD_EXPENSE & Total R\&D expenditure including grants and loans (Unit: 1,000 KRW) \\
\hline LN(RD_EXPENSE) & Natural log form of total R\&D expenditure including grants and loans \\
\hline KOR_APPLIED_PATENTS & The number of applied patents in Korea \\
\hline KOR_REGISTERED_PATENTS & The number of registered patents in Korea \\
\hline
\end{tabular}

Table 4. Technology index - Industry categorization

\begin{tabular}{cclc}
\hline Technology Index & Index & \multicolumn{1}{c}{ Industry Category } & Number of Companies \\
\hline High & 4 & $\begin{array}{l}\text { Aircraft and spacecraft, Pharmaceuticals, Office, } \\
\text { accounting, and computing machinery, Radio, TV, } \\
\text { and communications equipment, Medical, precision, } \\
\text { and optical instrument }\end{array}$ & 186 \\
\hline Medium-High & $3 \quad \begin{array}{l}\text { Electrical machinery and apparatus, Motor vehicles, } \\
\text { trailers, and semi-trailers, Chemicals excluding } \\
\text { pharmaceuticals, Railroad equipment and transport } \\
\text { equipment, Machinery and equipment }\end{array}$ & 400 \\
\hline Medium- Low & $\begin{array}{l}\text { Building and repairing of ships and boats, Rubber } \\
\text { and plastic products, Coke, refined petroleum } \\
\text { products and nuclear fuel, Other non-metallic mineral } \\
\text { products, Basic metals and fabricated metal products }\end{array}$ & 114 \\
\hline Low & $\begin{array}{l}\text { Manufacturing, Wood, pulp, paper products, printing, } \\
\text { and publishing, Food products, beverages and } \\
\text { tobacco, Textile, textile products, leather, and } \\
\text { footwear }\end{array}$ \\
\hline Others & Other industries that cannot be classified & 46 \\
\hline
\end{tabular}

\footnotetext{
*Source: OECD Science \& Technology Report, 2005
}

Table 5 gives the basic information of descriptive statistics including the sample size, minimum, maximum, and mean. We initially started with 1,000 firms, but we trimmed top and bottom $10 \%$ each of the number of applied and registered patents to eliminate possible outliers. After removing missing and invalid data, we were left with 756 firms as the total sample size. The majority of these firms are considered as technologically advanced. We took natural $\log$ form for the analysis, because the number of employees and R\&D expenditure has high variation. One interesting finding of the results of descriptive statistics is that the coefficients of variation of 
applied and registered patents do not vary much. From this, we can infer that applied patents are successfully registered at a consistent rate. However, the coefficient of variation of foreign ownership is relatively high, so we can conclude that foreign investors conduct considerable amount of research and analysis to identify attractive investment opportunity.

Table 5. Descriptive statistics

\begin{tabular}{|c|c|c|c|c|c|}
\hline Variable Name (unit) & Number & Minimum & Maximum & Mean & $\begin{array}{l}\text { Standard } \\
\text { Deviation }\end{array}$ \\
\hline EMPL_NUM (number of people) & 756 & 16 & 65,117 & 882 & 3,819 \\
\hline LN(EMPL_NUM) & 756 & 3 & 11 & 5 & 1 \\
\hline $\begin{array}{c}\text { RD_EXPENSE (1,000 Korean } \\
\text { won) }\end{array}$ & 756 & 227,273 & $4,399,365,508$ & $17,168,593$ & 1 \\
\hline LN(RD_EXPENSE) & 756 & 12 & 22 & 15 & 1 \\
\hline FR_OWNERSHIP (\%) & 412 & 0 & 87 & 9 & 12 \\
\hline $\begin{array}{c}\text { KOR_APPLIED_PATENTS } \\
\text { (number of patents) }\end{array}$ & 513 & 1 & 123 & 8 & 15 \\
\hline $\begin{array}{c}\text { KOR_REGISTERED_PATENTS } \\
\text { (number of patents) }\end{array}$ & 423 & 1 & 82 & 6 & 11 \\
\hline
\end{tabular}

\subsection{Regression Model \& Results}

After assessing the correlation between independent variables, we observe that there is a statistically significant correlation between the number of employees and R\&D expenditure with coefficient over 0.5 . Therefore, we analyzed the magnitude of multi-collinearity by looking at the size of VIF, which was around 1 . We interpreted this as follows: the standard error for the coefficient of that predictor variable is 1 times as large as it would be if R\&D expenditure were uncorrelated with the number of employees.

Table 6. Correlation coefficients

\begin{tabular}{|c|c|c|c|c|c|}
\hline & FR_OWNERSHIP & IND2 & TECHNOLOGY_INDEX & LN(EMPL_NUM) & LN(RD_EXPENSE) \\
\hline FR_OWNERSHIP & 1.000 & & & & \\
\hline IND2 & $-.183 * * *$ & 1.000 & & & \\
\hline TECHNOLOGY_INDEX & $-.328 * * *$ & $.266^{* * *}$ & 1.000 & & \\
\hline LN(EMPL_NUM) & $.489 * * *$ & $-.257 * * *$ & $-.434 * * *$ & 1.000 & \\
\hline LN(RD_EXPENSE) & $.394 * * *$ & -0.071 & $-.118 * *$ & $.593 * * *$ & 1.000 \\
\hline
\end{tabular}

We used three different dependent variables: R\&D expenditure, the number of applied patents, and the number of registered patents as they are interrelated. The regression equations in our study are as follows:

Regression (1): LN(RD_EXPENSE) $=\alpha+\beta_{1}$ FR_OWNERSHIP $+\beta_{2}$ IND2 $+\beta_{3}$ TECHNOLOGY_INDEX $+\beta_{4}$ LN(EMPL_NUM)

Regression (2): KOR_APPLIED_PATENTS $=\alpha+\beta_{1}$ FR_OWNERSHIP $+\beta_{2}$ IND2 $+\beta_{3}$ TECHNOLOGY_INDEX $+\beta_{4}$ LN(EMPL_NUM) $+\beta_{5}$ LN(RD_EXPENSE)

Regression (3): KOR_REGISTERED_PATENTS $=\alpha+\beta_{1}$ FR_OWNERSHIP $+\beta_{2}$ IND2 $+\beta_{3}$ TECHNOLOGY_INDEX $+\beta_{4}$ LN(EMPL_NUM) $+\beta 5$ LN(RD_EXPENSE) 
Table 7. Regression coefficients

\begin{tabular}{cccc}
\hline & Model $(1)-$ & Model $(2)-$ & Model (3) - \\
& LN(RD_EXPENSE) & KOR_APPLIED_PATENTS & KOR_REGISTERED_PATENTS \\
\hline Variables & & Standardized Coefficients \\
\hline FR_OWNERSHIP & $0.167^{* * *}$ & $0.12^{*}$ & $0.145^{* *}$ \\
\hline IND2 & $0.084^{* *}$ & -0.08 & $0.195^{* * *}$ \\
\hline TECHNOLOGY_INDEX & $0.213^{* * *}$ & $0.11^{*}$ & -0.026 \\
\hline LN(EMPL_NUM) & $0.724^{* * *}$ & 0.02 & 0.110 \\
\hline LN(RD_EXPENSE) & - & $0.35^{* * *}$ & $0.484^{* * *}$ \\
\hline Adjusted $R$ Square & 0.60 & 0.171 & 0.40 \\
\hline$F$ Value & $153.02^{* * *}$ & $13.795^{* * *}$ & $35.9 * * *$ \\
\hline$* * *: p<.01, * *: p<.05, *<.1$ & & &
\end{tabular}

Table 7 shows the regression coefficients model of our empirical model. Foreign ownership has statistically significant and positive coefficient with the number of applied and registered patents in Korea. In other words, as the foreign ownership increases, the corresponding $R \& D$ activities are promoted, thus the number of applied and registered patents also increase. As expected, R\&D expenditure has a statistically significant and positive correlation to both applied and registered patents. This demonstrates R\&D effort does lead to producing patents for high technology industries.

For Model (1), the adjusted R square is 0.60 , and this means that the independent variables predict $60 \%$ of the changes in R\&D expenditure. Similarly, the number of applied patents is explained $17 \%$ by its set of independent variables, and $40 \%$ for the number of registered patents. In other words, the foreign ownership percentage promotes R\&D activities significantly, and the output of this R\&D activity (i.e. applied and registered patents) experiences time-lag effects. Therefore, we can conclude that the percentage of foreign ownership has less impactful when it reaches applying or registered patent stages. We observe that the $\mathrm{F}$ value and adjusted $\mathrm{R}$ square of registered patents are relatively higher compared to those values of applied patents, and we can see that foreign investors tend to invest more towards companies that continuously innovate and perform better. As the technology index increases, we observe that R\&D expenditure and applied patents also increase; however, it does not have statistical significance to registered patents. Therefore, we conclude that many technologically advanced companies continue to perform R\&D for survival.

Table 8 and 9 show the coefficients by technology index of both applied and registered patents. As the technology advances, the coefficients of foreign ownership percentage were positive and increasing. The implication is that as the foreign ownership percentage increases, more patents are applied and registered for advanced technology industries. This can be explained by spillover effect of knowledge and technology and greater sample size. More specifically, most of the 756 companies in the sample were categorized as high or medium-high technology. However, these coefficients were not statistically significant. In the case of low technology, less knowledge and technology sharing takes place, and the sign of coefficient even is questionable. $R \& D$ expenditure is always statistically significant regardless technology index. Adjusted $R$ square values are fairly high. For example, the independent variables explain $14.5 \%$ of the applied patents for technologically most advanced industries. 
Table 8. Comparison of regression coefficients by technology index of applied patents

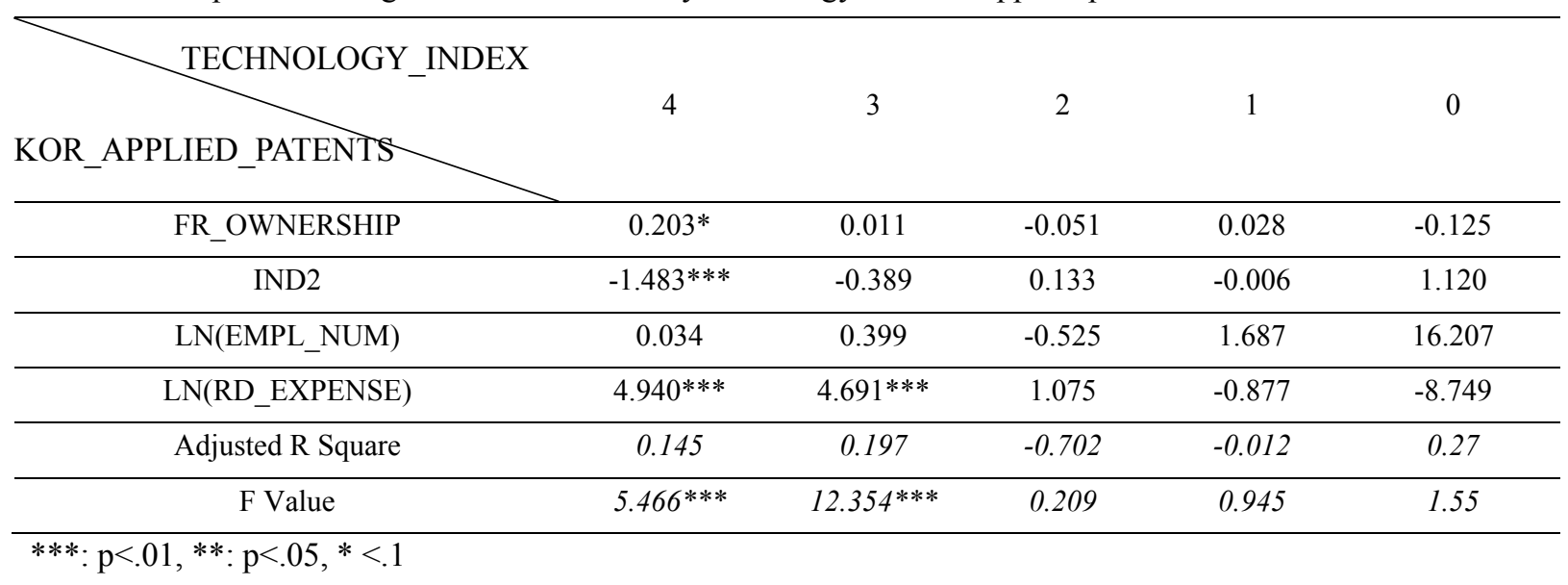

Table 9. Comparison of regression coefficients by technology index of registered patents

\begin{tabular}{cccccc}
\hline TECHNOLOGY_INDEX & & & & & \\
KOR_REGISTERED_PATENTS & 4 & 3 & 2 & 1 & 0 \\
\hline FR_OWNERSHIP & & & & & \\
\hline IND2 & 0.067 & 0.060 & -0.035 & -0.026 & 0.891 \\
\hline LN(EMPL_NUM) & $0.879^{* *}$ & 0.129 & $1.279^{*}$ & $0.999^{* * *}$ & 1.723 \\
\hline LN(RD_EXPENSE) & 0.456 & 0.919 & 0.151 & $6.241^{*}$ & 16.669 \\
\hline Adjusted R Square & $5.251^{* * *}$ & $7.141^{* * *}$ & $8.785^{* * *}$ & $7.704^{*}$ & -15.448 \\
\hline F Value & 0.280 & 0.423 & 0.501 & 0.736 & 0.783 \\
\hline$* * *: \mathrm{p}<.01, * *: \mathrm{p}<.05, *<.1$ & $8.776^{* * *}$ & $30.110^{* * *}$ & $9.047^{* * *}$ & $12.870^{* * *}$ & 6.414 \\
\hline
\end{tabular}

\section{Conclusion}

\subsection{Results and Implications}

Our empirical model shows a statistically significant and positive correlation between foreign ownership and the number of applied and registered patents in Korea from 1999 to 2009 based on Korean companies. It also shows that a positive correlation between foreign ownership and R\&D expenditure. This positive correlation can be explained by three main reasons.

First of all, as the foreign ownership increases, more sophisticated foreign investors from developed countries play an active role in introducing new technology, transfer of knowledge and know-how's, and critical decision making process. This leads to more R\&D activities and in the long run in applying and registering patents. This led more Korean companies such as Samsung Electronics, LG Electronics, and Hyundai Motors to be globally competitive with the next up-and-coming technology. This reasoning is also supported by previous studies in other developing countries such as India and Russia (Chuang \& Lin, 2007; Griffith, Redding \& Simpson, 2004; Vishwasrao and Bosshardt, 2001; Yudaeva, Kozlov, Melentie \& Ponomarva, 2003).

Secondly, a large majority of foreign investors investing in Korea are institutional or sophisticated individuals who are willing to take risks. For example, institutional investors who are vested for a long run are more risk-taking, thus this promotes R\&D activities (Cyert \& March, 1963). In other words, institutional investors value future growth, so they tend to invest in companies where $R \& D$ activities are active. The similar notion was observed in Taiwan as well (Huang \& Shiu, 2009).

Lastly, certain aspect of this positive correlation can be explained by the fact that foreign investors are investing in already successful firms - so called cherry picking effect. This was also observed in the case of India by Chhibber \& Majumdar (1999). In a market where large conglomerates dominate the majority of market share for 
most industries, investing in the winners will certainly lead to outperformance.

\subsection{Limitation and Future Studies}

Several areas can be improved in the future studies. First, the empirical analysis is based on sample data of Korean companies, so the results and implications cannot be applied directly to all countries. However, as proven by previous studies, it is applicable developing countries. There is a need to increase the sample size of firms for less technologically advanced industries as well if we wish to understand the broader implications of foreign investment in non-technology sectors. Secondly, we can also compare two different time frames: 1989-1999 to 1999-2009. The goal is to see how the change in Korea's foreign investment policy has changed the decision making process of R\&D activities in Korea. Lastly, there is ongoing discussion around how to measure innovation. Looking at the number of applied and registered patents is the most common way especially for technologically advanced industries, thus it is applicable in this empirical study. However, patents might not be the best indicator for non-R\&D intensive sectors such as service or retail. If there could be other better indicators such as the number of new products released, we could better measure innovation activities.

\section{References}

Bishop, P., \& Wiseman, N. (1999). External Ownership and Innovation in the United Kingdom. Journal of Applied Economics, 31(4), 443-450. http://dx.doi.org/10.1080/000368499324156

Boardman, A.E., Shapiro, D.M., \& Vining, A.R. (1997). The Role of Agency Costs in Explaining the Superior Performance of Foreign MNE Subsidiaries. International Business Review, 6(3), 295-317. http://dx.doi.org/10.1016/S0969-5931(97)00005-X

Chhibber, K., \& Majumdar, S. (1999). Foreign Ownership and Profitability: Property Rights, Control, and the Performance of Firms in Indian Industry. Journal of Law and Economics, 42(1), 209-238. http://dx.doi.org/10.1086/467423

Choe, H., Kho, B., \& Stulz, R.M. (2005). Do Domestic Investors Have an Edge? The Trading Experience of Foreign Investors in Korea. Review of Financial Studies, 18(3), 795-829. http://dx.doi.org/10.1093/rfs/hhi028

Chuang, Y.C., \& Lin, C.M. (2007). Foreign Direct Investment, R\&D, and Spillover Efficiency: Evidence from Taiwan's Manufacturing Firms. Journal of Development Studies, 35(4), 117-137. http://dx.doi.org/10.1080/00220389908422583

Cyert, R.M., \& March, J.G. (1963). A Behavioral Theory of the Firm. Englewood Cliffs Press, New Jersey.

David, P., \& Kochhar, R. (1996). Barriers to Effective Corporate Government by Institutional Investors: Implications for Theory and Practice. European Management Journal, 14(5), 457-466

Douma, S., George, R., \& Kabir, R. (2006). Foreign and Domestic Ownership, Business Groups, and Firm Performance: Evidence from a Large Emerging Market. Strategic Management Journal, 27(7), 637-657. http://dx.doi.org/10.1002/smj.535

Dvorak, T. (2005). Do Domestic Investors have an Information Advantage? Evidence from Indonesia. Journal of Finance, 60, 817-839.

Falk, M. (2008). Effect of Foreign Ownership on Innovation Activities: Empirical Evidence for Twelve European Countries. National Institute Economic Review, 204(1), 85-97. http://dx.doi.org/10.1177/00279501082040011001

Griffith, R., Redding, S.J., \& Simpson, H. (2004). Productivity Convergence and Foreign Ownership at the Establishment Level, CEPR Discussion Paper No 3756. Retrieved from http://ssrn.com/abstract=388802

Grinblatt, M., \& Keloharju, M. (2000). The Investment Behavior and Performance of Various Investor Types: A Study of Finland's Unique Data Set. Journal of Financial Economics, 55(1), 43-67. http://dx.doi.org/10.1016/S0304-405X(99)00044-6

Huang, R.D., \& Shiu, C.Y. (2009). Local Effects of Foreign Ownership in an Emerging Financial Market: Evidence from Qualified Foreign Institutional Investors in Taiwan. Journal of Financial Management, 38(3), 567-602. http://dx.doi.org/10.1111/j.1755-053X.2009.01048.x

Kang, J. K., \& Stulz, R. M. (1997). Why Is There a Home Bias? An Analysis of Foreign Portfolio Equity Ownership in Japan. Journal of Financial Economics, 46(1), 3-28. http://dx.doi.org/10.1016/S0304-405X(97)00023-8 
Kinoshita, Y. (2000). R\&D and Technology Spillover via FDI: Innovation and Absorptive Capacity, William Davidson Institute Working Paper No. 349. http://dx.doi.org/10.2139/ssrn.258194

Knell, M., \& Srholec, M. (2005). Innovation Cooperation and Foreign Ownership in the Czech Republic. Norwegian Institute for Studies in Innovation, 1-26.

Liu, Z. (2002). Foreign Direct Investment and Technology Spillover: Evidence from China. Journal of Comparative Economics, 30(3), 579-602. http://dx.doi.org/10.1006/jcec.2002.1789

Love, J.H., Ashcroft, B., \& Dunlo, S. (1996). Corporate Structure, Ownership, and the Likelihood of Innovation. Journal of Applied Economics, 28(3), 737-746. http://dx.doi.org/10.1080/000368496328489

Sasidharan, S., \& Kathuria, V. (2011). Foreign Direct Investment and R\&D: Substitutes or Complements - A Case of Indian Manufacturing after 1991 Reforms. World Development, 39(7), 1226-1239.

Vishwasrao, S., \& Bosshardt, W. (2000). Foreign Ownership and Technology Adoption: Evidence from Indian $\begin{array}{lllll}\text { Firms. Journal of Development } & \text { Economics, } & 65(2), & 367-387 .\end{array}$ http://dx.doi.org/10.1016/S0304-3878(01)00141-9

Yudaeva, K., Kozlov, K., Melentieva, N., \& Ponomareva, N. (2003). Does Foreign Ownership Matter? The Russian Experience. Journal of Economics of Transition, 11(3), 383-409. http://dx.doi.org/10.1111/1468-0351.00157

\section{Copyrights}

Copyright for this article is retained by the author(s), with first publication rights granted to the journal.

This is an open-access article distributed under the terms and conditions of the Creative Commons Attribution license (http://creativecommons.org/licenses/by/4.0/). 